\title{
Prevalence of Early Chronic Kidney Disease and Main Associated Factors in Spanish Population: Populational Study
}

\author{
Carmen Expósito 1,2, Guillem Pera ${ }^{2,3}$ (D) Lluís Rodríguez ${ }^{2,3}$, Ingrid Arteaga ${ }^{2,4}$, Alba Martínez ${ }^{2,5}$, \\ Alba Alumà ${ }^{6}$, María Doladé ${ }^{6}$, Pere Torán ${ }^{2,3}$ (D) and Llorenç Caballeria ${ }^{2,3, *(\mathbb{D})}$ \\ 1 Centro de Atención Primaria Sabadell Centro, Instituto Catalán de la Salud, 08021 Sabadell, Barcelona, Spain \\ 2 Fundació Institut Universitari per a la recerca a l'Atenció Primària de Salut Jordi Gol i Gurina (IDIAPJGol), \\ Unitat de Suport a la Recerca Metropolitana Nord, 08303 Mataró, Spain \\ 3 Centro de Investigación Biomédica en Red de Enfermedades Hepáticas y Digestivas (CIBEREHD), \\ 28029 Madrid, Spain \\ 4 Centro de Atención Primaria Santa Eulàlia, Instituto Catalán de la Salud, 08187 Santa Eulàlia de Ronçana, \\ Barcelona, Spain \\ 5 Centro de Atención Primaria La Llagosta, Instituto Catalán de la Salud, 08120 La Llagosta, Barcelona, Spain \\ 6 Laboratori Clínic Metropolitana Nord. Hospital Germans Trias i Pujol, 08916 Badalona, Spain \\ * Correspondence: lcaballeria.bnm.ics@gencat.cat; Tel.: +34-93-741-5338
}

Received: 26 July 2019; Accepted: 2 September 2019; Published: 4 September 2019

\begin{abstract}
The aim of this study was to determine the prevalence of early chronic kidney disease (EKD) (stages 1 and 2) and the factors associated. This was a populational study including individuals from 18-75 years randomly selected from 18 Primary Healthcare centers in the area of Barcelonès Nord and Maresme (Catalunya, Spain). Variables: anamnesis, physical examination, blood pressure, and analysis. EKD was defined with by a glomerular filtration rate (GFR) $\geq 60 \mathrm{~mL} / \mathrm{min} / 1.73 \mathrm{~m}^{2}$ and albumin/creatinine ratio (ACR) $\geq 17 \mathrm{mg} / \mathrm{g}$ in men and $\geq 25 \mathrm{mg} / \mathrm{g}$ in women confirmed with two determinations. 2871 individuals: 43\% men, mean age 55 years (19-75), 32.2\% obese, 50.5\% abdominal obesity, $21.1 \%$ hypertensive, and $10.6 \%$ diabetic. Prevalence of EKD: With one determination 157 individuals (5.5\%), 110 men (9\%) and 47 women (2.8\%); with two determinations 109 individuals $(3.8 \%), 85$ men $(7 \%)$, and 24 women $(1.5 \%)$. Factors independently associated with the multivariate logistic regression model: Man (OR 3.35), blood pressure $\geq 135 / 85 \mathrm{mmHg}$ (OR 2.29), BMI $\geq 30 \mathrm{~kg} / \mathrm{m}^{2}$ (OR 2.48), glycemia $\geq 100 \mathrm{mg} / \mathrm{dL}$ (OR 1.73), smoker (OR 1.67) and age (OR 1.04). The prevalence varies if the diagnosis is established based on one or two analytical determinations, overestimated if only one determination is made and depends on the value chosen to define urine albumin excretion.
\end{abstract}

Keywords: chronic kidney disease; prevalence; associated factors; albuminuria; obesity; arterial hypertension; type 2 diabetes

\section{Introduction}

Recent papers in the literature have clearly shown that chronic kidney disease (CKD) is one of the main causes of morbidity and mortality in Western countries. Disease progression to the final stages of the disease requiring substitutive treatment with dialysis or kidney transplant leads to an important reduction in the quality of life of these patients and is an enormous economic burden to the healthcare system [1]. In addition, the associated cardiovascular complications are even more frequent than evolution to terminal disease, making the prevention, early detection and treatment of this disease by non-specialist physicians should be a priority [2]. CKD is defined as a reduction in the glomerular filtration rate (GFR) to less than $60 \mathrm{~mL} / \mathrm{min} / 1.73 \mathrm{~m}^{2}$ or the presence of markers of renal damage (mainly 
albumin values greater than or equal to $30 \mathrm{mg} /$ day) during three months or more, independently of the cause, with adverse consequences for health [3,4]. According to the current KDIGO (Kidney Disease: Improving Global Outcomes) classification there are five stages of CKD based on the GFR and the presence of albuminuria; stages 1 and 2 correspond to a GFR $\geq 60 \mathrm{~mL} / \mathrm{min} / 1.73 \mathrm{~m}^{2}$, and the presence of albuminuria corresponds to early disease (EKD) or the onset of kidney disease [3,5].

Most studies measured the global prevalence of CKD, mainly focused in the advanced, 3, 4 and 5, stages of the disease. These studies showed great variability in the prevalence of CKD because of the different design of the studies, the methodology used, the diagnostic criteria, and the lack of standardization of the laboratory values. Taking these factors into account, the prevalence of EKD ranges from 1 to 30\% [6-16]. Although many studies have determined the presence of albuminuria, only few studies have focused in the prevalence of EKD. With the different methodologies used in studies to evaluate the presence of albuminuria, urine strip [17], excretion methods [18] or concentrations $[5,7,19,20], 24-\mathrm{h}[18]$ or random urine $[5,7,17,19,20]$, as well as a unique albuminuria measurement, the prevalence of EKD varies from 2.29\% [19] to 28.6\% [7]. There is currently consensus that the best method to evaluate albuminuria and to reduce this variability is to calculate the albumin/creatinine ratio (ACR) in the first urine of the morning [21].

An ACR greater than or equal to $30 \mathrm{mg} / \mathrm{g}$ of creatinine is usually considered to determine the presence of pathological albumin levels in urine $[3,4,22,23]$. However, some guidelines and groups of experts lowered this value in this limit as $17 \mathrm{mg} / \mathrm{g}$ for men and $25 \mathrm{mg} / \mathrm{g}$ for women [24-26], since these values have the best correlation with urine albumin excretion less than $30 \mathrm{mg} /$ day, which is the normal value for healthy individuals. In addition, these values minimize, in part, the underdiagnosis of EKD in men [27].

In order to develop programmes at a populational level and avoid the progression of EKD to a more advanced stages, and the risk of associated complications, it is necessary to determine the prevalence and the characteristics of the population affected as accurately as possible from the earliest stages of the disease (stages 1 and 2) because these stages already are an independent risk marker for the development of subclinical arteriosclerosis [5] and cardiovascular disease [28]. The aim of this study was to determine the prevalence of EKD (stages 1 and 2) and the factors associated with this disease.

\section{Materials and Methods}

\subsection{Study Design and Population}

The study was carried out using a sample selected for the "detection of liver diseases in the general population" [29]. A descriptive, transversal, multicenter, population-based study was designed including individuals ascribed to 18 Primary Healthcare Centers of the area of Barcelonès Nord and Maresme (Catalonia, Spain), which covers to population of 470,000 inhabitants.

The sample was randomly selected from the database of the Primary Care Information System (SIAP) which includes all individuals with national healthcare cards and is equivalent to the population census of Catalonia, Spain. This database includes all the individuals ascribed to a Primary Healthcare Centre of the zone, regardless of whether they have been attended or not. All the candidates were invited to participate by a telephone call. For subjects accepting to participate a visit was programmed with a trained nurse who performed the anamnesis, physical examination and basal blood analyses.

The inclusion criteria were: population of both genders from 18-75 years of age ascribed to the participating Primary Healthcare Centers, who voluntarily and provided written informed consent accepted to participate in the study.

The exclusion criteria were: CKD stages 3, 4 and 5; subjects with severe disease in advanced stage and/or clinically unstable (heart failure, chronic obstructive pulmonary disease or cancer) or conditions making data collection and follow-up difficult, such as incapacitating conditions, cognitive impairment or individuals in long-term care facilities. 
The protocol was approved by the Ethics Committee of the Fundació Gol i Gorina (P11/58) (Barcelona, Spain) which followed the Declaration of Helsinki. All subjects provided written informed consent before inclusion.

\subsection{Study Variables}

\subsubsection{Sociodemographic Variables: Age, Gender}

- Age: Age in years in subjects between 18 and 75 years

- Gender: Males and females

\subsubsection{Anamnesis}

- Presence of comorbidities. This was determined by review of the clinical history: arterial hypertension (AHT), type 2 diabetes mellitus (DM2), hypercholesterolemia and hypertriglyceridemia.

- Alcohol intake. The consumption of alcohol was recorded as standard drink units (SDU), and intake during the week and the weekends was differentiated. The length of consumption in years was also recorded. One SDU is equivalent to $10 \mathrm{~g}$ of alcohol. Consumption per week $\geq 21 \mathrm{SDU}$ in men and $\geq 14$ SDU in women was considered to be of risk.

- Tobacco consumption: This included never smokers, ex-smokers (more than 1 years without smoking) and active smokers.

\subsection{Physical Examination}

Anthropometric data: weight $(\mathrm{kg})$, height $(\mathrm{cm})$, abdominal obesity $(\mathrm{cm})$ and body mass index (BMI) calculated according to the weight formula ( $\mathrm{kg}$ weight $/ \mathrm{m}^{2}$ height). Abdominal obesity was measured by determining the waist circumference using a metric measuring tape (waist circumference is considered the perimeter of the intermediate abdominal zone between the last costal arch and the iliac crest measured on a horizontal plane).

Determination of blood pressure (BP): this was performed with the subject in a seated position with a validated (OMRON M6 Comfort) blood pressure monitor. Three measurements were made separated by two minutes each, and the mean of the last two measurements was taken as the blood pressure value, discarding the first measurement.

\subsection{Analytical Determinations.}

Blood analyses were performed after $12 \mathrm{~h}$ of fasting and included the determination of: complete blood count, basal glycemia, glycosylated hemoglobin, total cholesterol, HDL-cholesterol, LDL-cholesterol, triglycerides, serum creatinine, GFR, and ACR in the first morning urine.

\subsection{Diagnosis of EKD}

According to the KDIGO guidelines, EKD is considered to be before stages 1 and 2 [3] and includes individuals with a GFR $\geq 60 \mathrm{~mL} / \mathrm{min} / 1.73 \mathrm{~m}^{2}$ and the presence of albuminuria. The GFR was first calculated using the MDRD-4 (Modification of Diet in Renal Disease-4) formula [30,31] which was used by the reference laboratory at the beginning of the study and afterwards, the new CKD-EPI (Chronic Kidney Disease Epidemiology Collaboration) formula [32] was implemented by the reference laboratory. The presence of albuminuria was determined using the ACR in the first urine of the morning. The cut-offs for defining the presence of pathological albuminuria were $\geq 17 \mathrm{mg} / \mathrm{g}$ in men and $\geq 25 \mathrm{mg} / \mathrm{g}$ in women. An altered value required confirmation with a second determination in no less than 3 months. In the case of discordance between the first and second urine albumin values (first sample altered and second normal), a third determination was made in no less than 3 months following the second measurement to definitively confirm or rule out the presence of albuminuria (Figure 1). 


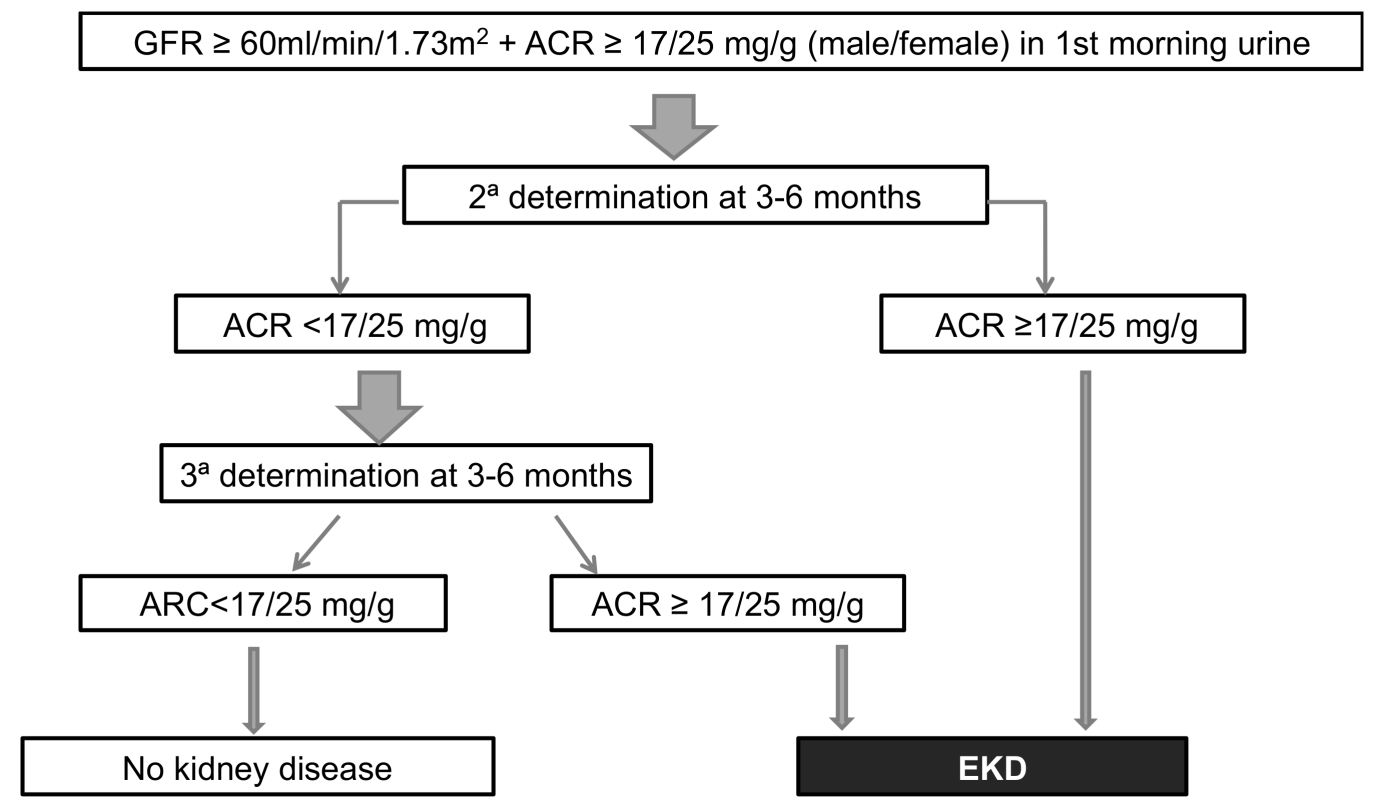

Figure 1. Diagnosis of early kidney disease (EKD).

\subsection{Statistical Analysis}

For data collection, a notebook was designed to register each of the variables of anamnesis, physical examination, and the analytical results. A database was developed in an Excel spreadsheet, with all the variables being introduced with the double entry method. Exhaustive quality control of the data was performed.

The variables are expressed are frequencies and percentages when categorical and as mean and standard deviation (SD) when quantitative. However, clearly asymmetric values are shown as median and interquartile range (IQR).

Bivariate comparisons were carried out with the Chi-square test to compare categorical variables using the Fisher exact test when the expected frequency in some domain was less than 5 . Continuous variables were compared with the Student's t test, using the Mann-Whitney test if the data were expressed as medians.

The prevalences were calculated with their respective $95 \%$ confidence intervals $(95 \% \mathrm{CI})$.

The multivariate relation between a dependent dichotomic variable (i.e., kidney disease: yes/no) and the potential explanatory and confounding factors were studied by logistic regression models obtaining odds ratios (OR) and their 95\%CI adjusted for all the variables introduced in the model (shown in the tables). Variables showing a significant relationship in the bivariate models were included. When some explanatory variables were strongly correlated, one was chosen (that with the greatest biological plausibility or which had a greater effect on the bivariate model) to avoid collinearity.

All the statistical tests were performed bilaterally with a significance of $5 \%$. The analyses were performed with the Stata v15 statistical package.

\section{Results}

The study was carried out from 27 March 2012 to 30 June 2016. The population from 18 to 75 years of age assigned to the participating primary care centers included 162.950 inhabitants. Of these, 3.460 individuals were randomly selected to initially be invited to participate in the detection of liver diseases in a healthy population, with $3.060(62.8 \%)$ accepting to participate. After purification of the data for analysis, 22 individuals diagnosed with stages 3, 4 or 5 CKD and 167 in whom no urine sample was available were excluded. A total of 2.871 individuals were finally analyzed (Figure 2). 


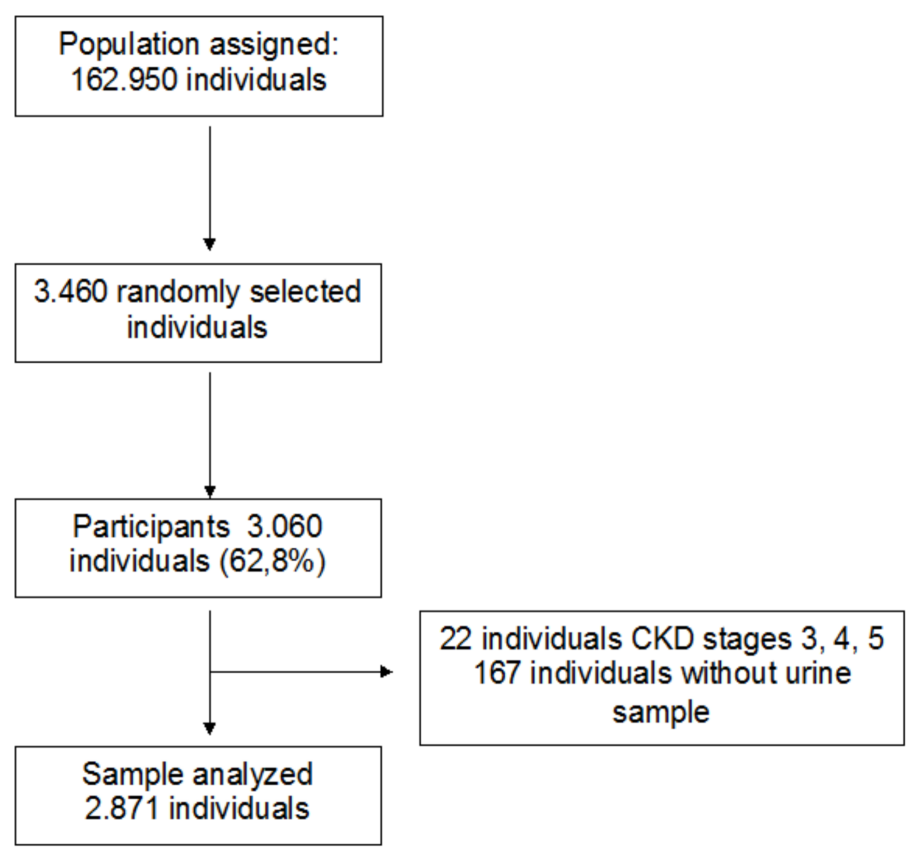

Figure 2. Diagram of participation.

\subsection{Characteristics of the Sample}

Of the sample analyzed 1.222 individuals were men (43\%) and 1.649 women $(57 \%)(p<0.001)$, with a mean age of 55 years ( $\mathrm{SD} \pm 12$ years) (range: 19-75 years). Participation by age groups was as follows: 569 individuals (19.8\%) between 19-44 years of age, 689 individuals (24\%) between 45-54 years, 966 individuals (33.6\%) between 55-64 years, and 647 individuals (22.5\%) were in the 65-75 year age group $(p<0.001)$. Table 1 shows the main clinical characteristics of the study sample. Among the alcohol consumers (50\%), 9.2\% were drinkers of risk $(p<0.001)$. With respect to weight, 32.2\% were obese, $41.6 \%$ presented overweight and $50.5 \%$ had abdominal obesity. Among the sample, $27.1 \%$ had hypertension, and $10.6 \%$ were diabetics.

\subsection{Prevalence of EKD}

In 157 individuals (5.5\%) (110 men (9\%) and 47 women $(2.8 \%)$ ) the GFR was $\geq 60 \mathrm{~mL} / \mathrm{min} / 1.73 \mathrm{~m}^{2}$, and the ACR was $\geq 17 \mathrm{mg} / \mathrm{g}$ in men and $\geq 25 \mathrm{mg} / \mathrm{g}$ in women. Of these, $109(3.8 \%)(85 \mathrm{men}(7 \%)$ and 24 women (1.5\%)) presented an ACR above the reference value in the second or third determinations $(p<0.001)$. Therefore, the global prevalence of EKD was 3.8\% (Figures 3 and 4$)$. With an ACR cut-off of $30 \mathrm{mg} / \mathrm{g}$ for both genders, 103 individuals (3.6\%) (73 men (6\%) and 30 women (1.8\%)) presented an ACR above this value in the first determination $(p<0.001)$, which was confirmed in 62 individuals $(2.1 \%)$ (47 men (3.8\%) and 15 women (1\%), in the second or third determination (Figures 3 and 4 ). 


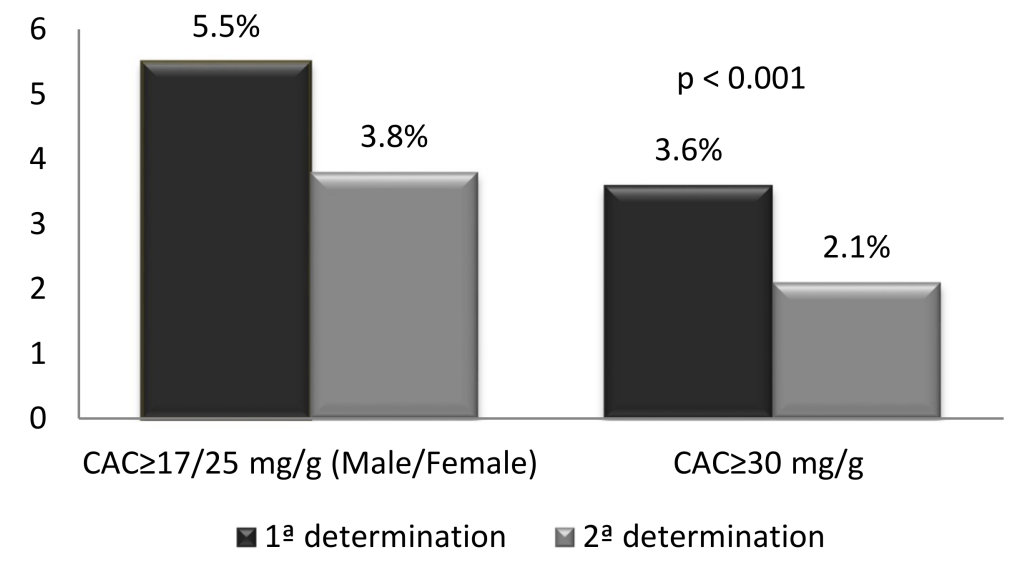

Figure 3. Prevalence of early kidney disease according to cut-off values.

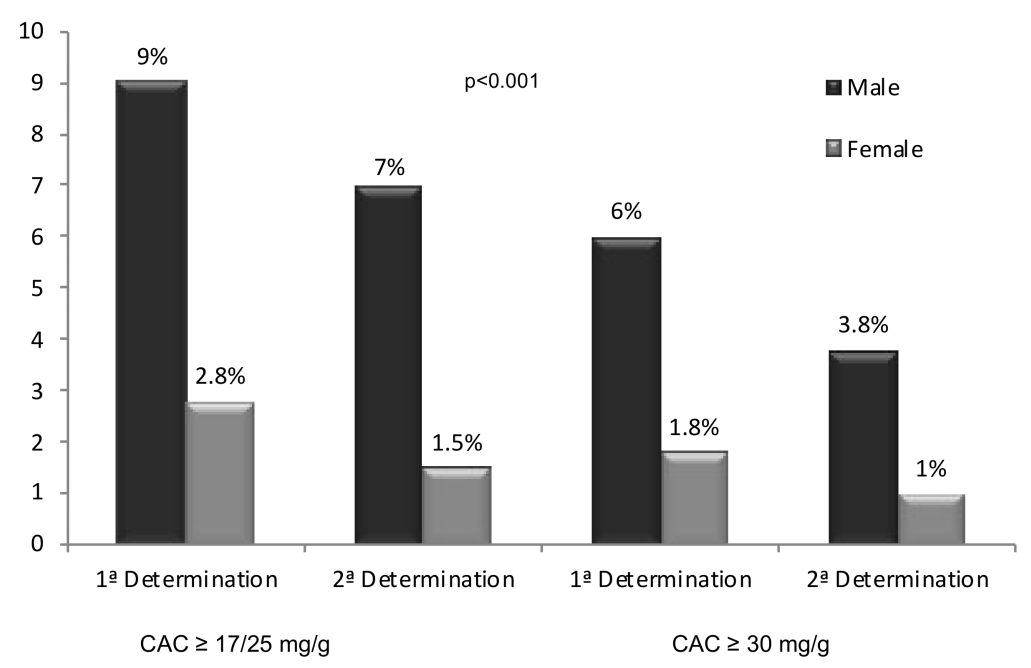

Figure 4. Prevalence of early kidney disease by gender.

According to the different age groups, the prevalence of EKD was: $1.2 \%$ between 19 and 44 years, $2.2 \%$ between 45 and 54 years, $3.9 \%$ between 55 and 64 years and $7.6 \%$ between 65 and 75 years of age. The trend to an increase with age was also observed according to gender $(p<0.001)$ (Figure 5$)$.

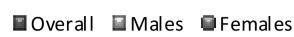

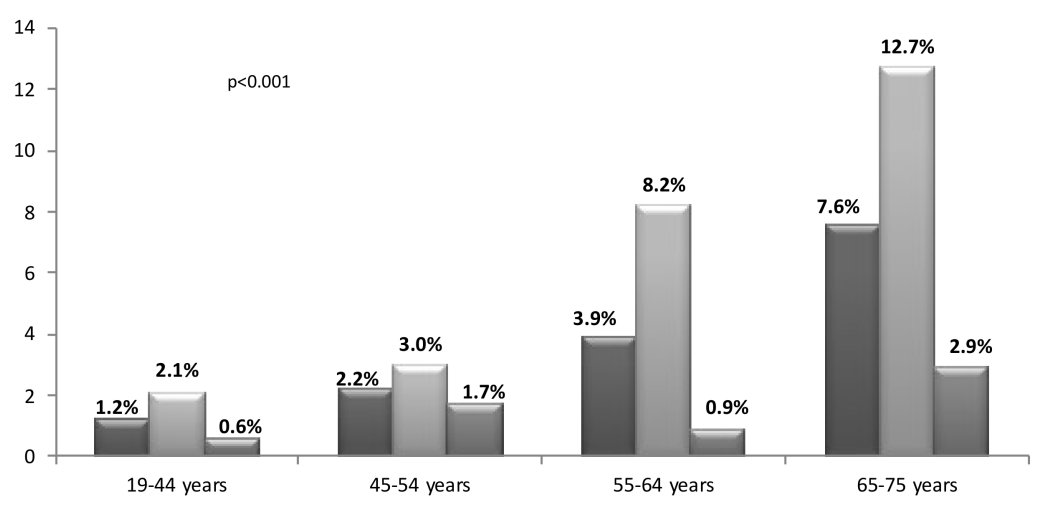

Figure 5. Prevalence of early kidney disease by age groups and gender. 


\subsection{Principal Associated Factors}

Table 1 shows the main comorbidities and clinical and analytical parameters associated with EKD. These were: AHT $(8.4 \% ; p<0.001)$ and DM2 $(15.4 \% ; p<0.001)$ registered in the clinical history of the patients, blood pressure (BP) $\geq 135 / 85 \mathrm{mmHg}(6.4 \% ; p<0.001)$, glycemia $\geq 100 \mathrm{mg} / \mathrm{dL}(7 \% ; p<0.001)$, $\mathrm{BMI} \geq 30 \mathrm{~kg} / \mathrm{m}^{2}(6.7 \% ; p<0.001)$, abdominal obesity $(4.9 \% ; p=0.001)$, triglycerides $\geq 150 \mathrm{mg} / \mathrm{dL}(6.8 \%$; $p<0.001)$ and HDL-cholesterol $<40 \mathrm{mg} / \mathrm{dL}$ in men and $<50 \mathrm{mg} / \mathrm{dL}$ in women $(5.1 \% ; p=0.086)$.

Table 1. Baseline characteristics of the 2871 subjects included in the study and associated factors according to the presence of early kidney disease (EKD).

\begin{tabular}{|c|c|c|c|c|c|c|c|}
\hline \multirow{3}{*}{ Variables } & \multicolumn{4}{|c|}{ EKD } & \multirow{2}{*}{\multicolumn{3}{|c|}{ Total }} \\
\hline & \multicolumn{2}{|c|}{ No } & \multicolumn{2}{|c|}{ Yes } & & & \\
\hline & $\mathbf{n}$ & $\%$ & $\mathrm{n}$ & $\%$ & $\mathbf{n}$ & $\%$ & $p$ \\
\hline Gender & & & & & & & $<0.001$ \\
\hline Males & 1137 & $93.0 \%$ & 85 & $7.0 \%$ & 1222 & $43.0 \%$ & \\
\hline Females & 1625 & $98.5 \%$ & 24 & $1.5 \%$ & 1649 & $57.0 \%$ & \\
\hline Age & & & & & & & $<0.001$ \\
\hline $19-44$ & 562 & $98.8 \%$ & 7 & $1.2 \%$ & 569 & $19.8 \%$ & \\
\hline $45-54$ & 674 & $97.8 \%$ & 15 & $2.2 \%$ & 689 & $24.0 \%$ & \\
\hline $5-64$ & 928 & $96 . \%$ & 38 & $3.9 \%$ & 966 & $33.6 \%$ & \\
\hline $65-75$ & 598 & $92.4 \%$ & 49 & $7.6 \%$ & 647 & $22.5 \%$ & \\
\hline Mean, $( \pm S D)$ & 55 & 12 & 61 & 9 & 55 & 12 & $<0.001$ \\
\hline Tobacco & & & & & & & $<0.001$ \\
\hline Non smoker & 1339 & $98.0 \%$ & 28 & $2.0 \%$ & 1367 & $47.6 \%$ & \\
\hline Former smoker & 778 & $93.4 \%$ & 55 & $6.6 \%$ & 833 & $29.0 \%$ & \\
\hline Current smoker & 633 & $96.3 \%$ & 24 & $3.7 \%$ & 657 & $22.9 \%$ & \\
\hline Alcohol & & & & & & & $<0.001$ \\
\hline Never drinker & 1392 & $97.1 \%$ & 42 & $2.9 \%$ & 1434 & $50.0 \%$ & \\
\hline Moderate drinker ${ }^{1}$ & 1123 & $96.1 \%$ & 45 & $3.9 \%$ & 1168 & $40.6 \%$ & \\
\hline Risk drinker & 244 & $91.7 \%$ & 22 & $8.3 \%$ & 266 & $9.2 \%$ & \\
\hline Obesity & & & & & & & $<0.001$ \\
\hline Normoweight (BMI < 25 kg/m²) & 741 & $98.8 \%$ & 9 & $1.2 \%$ & 750 & $26.2 \%$ & \\
\hline Overweight $\left(25 \leq \mathrm{BMI}<30 \mathrm{~kg} / \mathrm{m}^{2}\right)$ & 1153 & $96.8 \%$ & 38 & $3.2 \%$ & 1191 & $41.6 \%$ & \\
\hline Obese $\left(\mathrm{BMI} \geq 30 \mathrm{~kg} / \mathrm{m}^{2}\right)$ & 859 & $93.3 \%$ & 62 & $6.7 \%$ & 921 & $32.2 \%$ & \\
\hline Abdominal obesity ${ }^{2}$ & & & & & & & 0.001 \\
\hline No & 1373 & $97.4 \%$ & 36 & $2.6 \%$ & 1409 & $49.5 \%$ & \\
\hline Yes & 1368 & $95.1 \%$ & 71 & $4.9 \%$ & 1439 & $50.5 \%$ & \\
\hline Arterial hypertension & & & & & & & $<0.001$ \\
\hline No & 2049 & $97.9 \%$ & 44 & $2.1 \%$ & 2093 & $72.9 \%$ & \\
\hline Yes & 713 & $91.6 \%$ & 65 & $8.4 \%$ & 778 & $27.1 \%$ & \\
\hline Blood pressure $(\geq 130 / 85 \mathrm{mmHg})$ & & & & & & & $<0.001$ \\
\hline No & 1548 & $98.3 \%$ & 26 & $1.7 \%$ & 1574 & $55.0 \%$ & \\
\hline Yes & 1205 & $93.6 \%$ & 83 & $6.4 \%$ & 1288 & $45.0 \%$ & \\
\hline Type-2 diabetes & & & & & & & $<0.001$ \\
\hline No & 2504 & $97.6 \%$ & 62 & $2.4 \%$ & 2566 & $89.4 \%$ & \\
\hline Yes & 258 & $84.6 \%$ & 47 & $15.4 \%$ & 305 & $10.6 \%$ & \\
\hline Glucose ( $\geq 100 \mathrm{mg} / \mathrm{dL})$ & & & & & & & $<0.001$ \\
\hline No & 1776 & $98.0 \%$ & 37 & $2.0 \%$ & 1813 & $63.7 \%$ & \\
\hline Yes & 963 & $93.0 \%$ & 72 & $7.0 \%$ & 1035 & $36.3 \%$ & \\
\hline $\mathrm{HDL}<40 / 50 \mathrm{mg} / \mathrm{dL}$ (Male/Female) & & & & & & & 0.086 \\
\hline No & 2184 & $96.5 \%$ & 80 & $3.5 \%$ & 2264 & $79.9 \%$ & \\
\hline Yes & 542 & $94.9 \%$ & 29 & $5.1 \%$ & 571 & $20.1 \%$ & \\
\hline Triglycerides ( $\geq 150 \mathrm{mg} / \mathrm{dL})$ & & & & & & & $<0.001$ \\
\hline No & 2076 & $97.1 \%$ & 61 & $2.9 \%$ & 2137 & $75.3 \%$ & \\
\hline Yes & 653 & $93.2 \%$ & 48 & $6.8 \%$ & 701 & $24.7 \%$ & \\
\hline
\end{tabular}

${ }^{1}$ Moderate drinker consumption per week $<21$ SDU in men and $<14$ in women. ${ }^{2}$ Waist circumference $\geq 102 \mathrm{~cm}$ in men or $\geq 88 \mathrm{~cm}$ in women. 
Figures 6 and 7 show the prevalence of these factors and comorbidities in the 109 individuals with EKD.

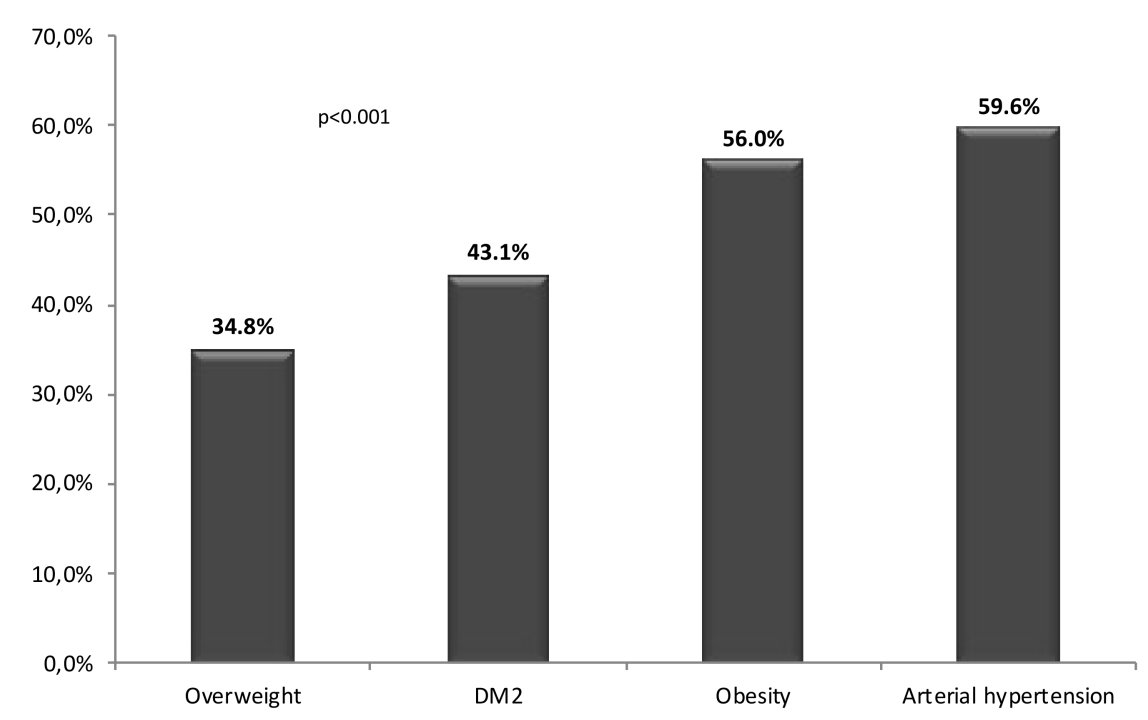

Figure 6. Prevalence of comorbidities in the population affected by early kidney disease.

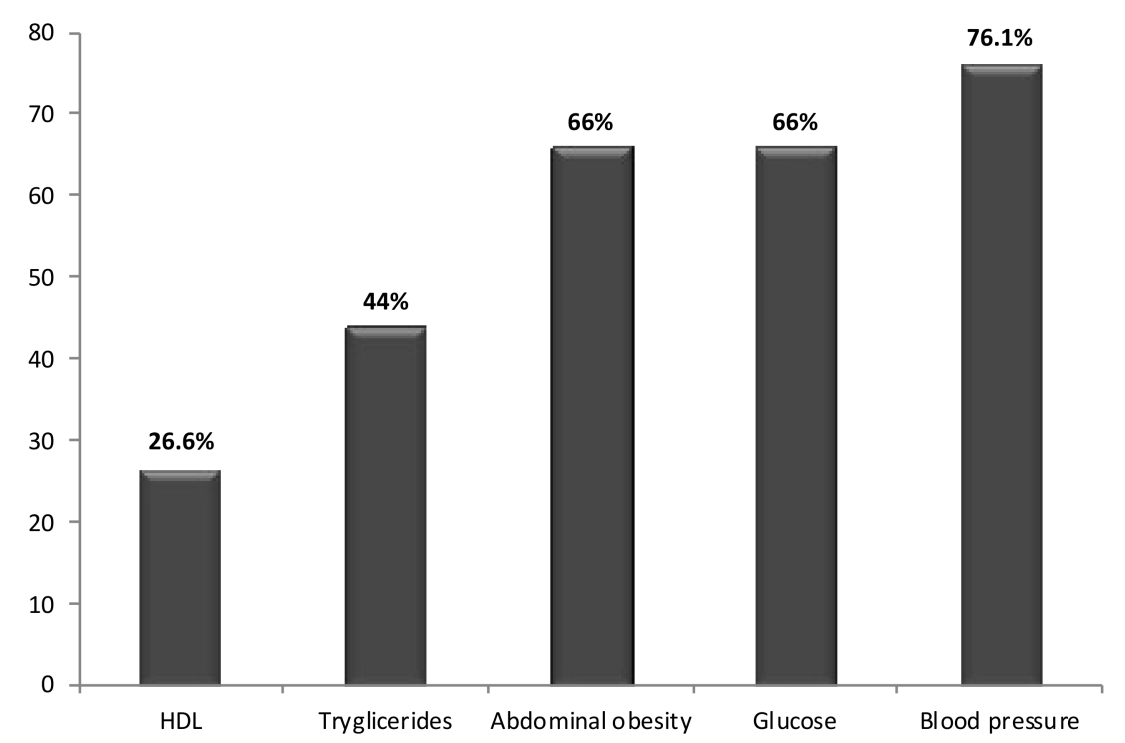

Figure 7. Prevalence of associated factors in the population with early kidney disease.

The factors independently associated with EKD in the multivariate logistic regression model were: male gender (OR 3.35; 95\%CI 1.98-5.68), BP $\geq 135 / 85 \mathrm{mmHg}$ (OR 2.29; 95\%CI 1.41-3.70), BMI $\geq 30 \mathrm{~kg} / \mathrm{m}^{2}$ (OR 2.48; 95\%CI 1.18-5.20), glycemia $\geq 100 \mathrm{mg} / \mathrm{dl}$ (OR 1.73; 95\%CI 1.12-2.67), smoking habit (OR 1.67; 95\%CI 1.02-2.73) and age (OR 1.04; 95\%CI 1.02-1.07) (Table 2). 
Table 2. Risk factors associated with early kidney disease.

\begin{tabular}{ccccc}
\hline & OR & \multicolumn{2}{c}{ IC95\% } & $p$ \\
\hline Age (per year) & 1.04 & 1.02 & 1.70 & 0.001 \\
Male gender & 3.35 & 1.98 & 5.68 & 0.001 \\
Smoker & 1.67 & 1.02 & 2.73 & 0.042 \\
Overweight $\left(25 \leq \mathrm{BMI}<30 \mathrm{~kg} / \mathrm{m}^{2}\right)$ & 1.35 & 0.63 & 2.87 & 0.440 \\
Obesity $\left(\mathrm{BMI} \geq 30 \mathrm{Kg} / \mathrm{m}^{2}\right)$ & 2.48 & 1.18 & 5.20 & 0.016 \\
Blood pressure $(\geq 130 / 85 \mathrm{mmHg})$ & 2.29 & 1.41 & 3.70 & 0.001 \\
Fasting glucose $(\geq 100 \mathrm{mg} / \mathrm{dL})$ & 1.73 & 1.12 & 2.67 & 0.013 \\
Triglycerides $(\geq 150 \mathrm{mg} / \mathrm{dL})$ & 1.51 & 1.00 & 2.29 & 0.053 \\
\hline
\end{tabular}

\section{Discussion}

The initial phases of CKD are silent and the prevalence is non negligible, having an important economic burden and social impact, especially in the end-stages. This has led to re-examination of the concept of this disease [33] and the development of populational programs for early detection and control by public health organisms to avoid comorbidities and progression to advanced phases. The prevalence of EKD in the present study was 3.8\%. To our knowledge this is the first study on the detection of CKD in the early stages and the factors associated with the disease and in which the term "chronicity" is determined, confirming the persistence of the alteration of the kidney lesion after 3 months as recommended in the current guidelines of clinical practice [3,4].

Among the strengths of the present study, the following are of note: (1) the important number of subjects recruited, with a participation of $62.8 \%$ providing a representative sample of the general population of both genders, and (2) the populational character of the study with a totally random selection of participants made from the SIAP primary care database, which is even more up to date than the registry of the population census.

It is difficult to compare the prevalence observed in our study with other studies in the literature because of the important variability among studies in relation to not only the study populations but also the methodology used for the diagnosis of kidney disease [34,35]. Most of the epidemiological studies performed have evaluated the prevalence of CKD based on a single analytical determination of the GFR and albuminuria [6-12,14-16,19,36], despite current consensus that the diagnosis should be established on the presence of two altered analytical samples separated by at least 3 months $[3,4]$, as was done in the present study, which mean an important difference with other published studies in general population and may result in significant variations in the prevalence of this entity. This is especially important in determined situations such as exercise, fever or systemic infections, cystitis or generalized inflammatory processes, among others, in which the permeability of the glomerular membrane may be transitorily increased to later return to its basal state. Confirming the presence of a chronic lesion with a second determination after a certain period of time avoids overdiagnosis due to these variations [36-39]. Although this study did not register these clinical situations, this may explain why an alteration of the ACR was observed in 5.5\% of the sample and reduced to $3.8 \%$ when the measurement was repeated a second or third time 3 to 5 months later.

On the other hand, the prevalence of CKD also differs according to the cut-off established to define the presence of pathological albuminuria, and this was also observed in the present study. In most guidelines, including the KDIGO and the consensus statement of the Spanish Nephrology Society $[3,4,22,23]$, this cut-off is an ACR $\geq 30 \mathrm{mg} / \mathrm{g}$ in both genders, considering that above this value the risk of global mortality, progression to $C K D$, cardiovascular disease and exacerbation of CKD is greater [40]. However, the relationship between albuminuria and the risk of renal and cardiovascular complications is a continuous variable [41,42]. If we accept a cut-off of $30 \mathrm{mg} / \mathrm{g}$, the prevalence of EKD which we observed with a single ACR determination was 3.6\%, decreasing to $2.1 \%$ with the second or third confirmatory determination. This prevalence is similar to that observed in the Spanish EPIRCE (Epidemiology of Chronic Renal Insufficiency in Spain) populational study in which $2.29 \%$ of the 
population presented EKD, although this result was obtained with a single ACR determination [19]. The prevalences reported in the NHANES questionnaire (The National Health and Nutrition Examination Survey) 1988-1994 and 1999-2004 were higher, with 4.4\% and 5\%, respectively [7], which may have been explained by the greater prevalence of factors associated with CKD in the American population. The prevalence described in the KHANES survey in the Korean population was also higher at $5.7 \%$, but in this study, albuminuria was determined using the urine strip [43]. This wide variability in the prevalence of CKD has also been observed in countries of the European Union (EU), ranging from the $3.31 \%$ reported in Norway to $17.3 \%$ in north-east Germany. These differences remained after adjustment for diabetes mellitus, AHT and obesity, which are considered to be important risk factors of CKD [34]. The different study populations, genetic variability of the different ethnicities or in different territories and the heterogeneity of the laboratory methods for measuring and storing both serum creatinine and albuminuria $[44,45]$ contribute to these differences.

The results of the prevalence of CKD according to gender are also controversial depending on the threshold value to define the presence of albuminuria. In the present study ACR values $\geq 17$ in men and $\geq 25 \mathrm{mg} / \mathrm{g}$ in women, showed EKD to be present in $7 \%$ of men and $1.5 \%$ of women, being clearly higher in men. In the NHANES 1999-2000 study, the prevalence was higher among women and the EPIRCE study described a greater prevalence in men, but the differences were not significant. In both studies, the ACR cut-off was $30 \mathrm{mg} / \mathrm{g}$ for both genders. In the present study, this cut-off also showed a higher prevalence in men, being statistically significant regardless of whether a single or two ACR determinations were made. However, the use of this cut-off for both genders may underestimate the prevalence of kidney damage in men $[19,46]$. In normal conditions, the ACR value is higher in women since urine albumin excretion is practically the same in both genders, but creatinine excretion is greater in men because of the greater muscle mass they present [47]. Therefore, some scientific guidelines and societies $[26,48,49]$ have established cut-off values $\geq 17 \mathrm{mg} / \mathrm{g}$ for men and $\geq 25 \mathrm{mg} / \mathrm{g}$ for women as indicative of the pathological presence of albuminuria, because these are the values which best correlate with the albumin excretion of $30 \mathrm{mg} / \mathrm{d}$ considered to be the maximum in healthy individuals [27].

Age is a clear factor of risk for the appearance of CKD in all its stages $[7,34,35,43,46,48]$, and the present study showed an increase in the prevalence of EKD in the older age groups, being greater in men of any age group. This trend was also observed in other studies in Spain and other countries $[5,7,19,34]$. Despite this, some authors have questioned the clinical repercussion which the appearance of CKD may have with age in regard to both the progression of the disease and its associated complications. A reduction in the GFR is a physiological condition inherent to aging. Indeed, some studies have reported that the relative risks associated with the complications of CKD do not increase in more advanced age groups, but rather aging itself leads to underlying endothelial dysfunction which extends to the arterial territory throughout the organism, producing generalized arteriosclerosis which would explain this increase of risk with age. The presence of albuminuria is the translation of this dysfunction at a glomerular level [40,42].

Apart from gender and age, the most important risk factors determining the appearance and progression of CKD are DM2, AHT, and obesity, together with smoking [50]. Of note in the present study was the high prevalence of overweight and obesity observed, with up to $73 \%$ of the sample presenting a BMI $\geq 25 \mathrm{~kg} / \mathrm{m}^{2}$. This result is consistent with the trend to an increase in obesity in Western countries in the last years [51,52] and explains, in part, the increase in EKD. The prevalence of EKD in our obese population was $6.7 \%$, being significantly greater than the $1.2 \%$ found in individuals with normal weight and is similar to that of other countries in the EU [34]. At a pathophysiological level, the synthesis and release of fatty acids in obesity leads to a chronic state of mild inflammation which has a direct impact on renal damage and the appearance of the remaining metabolic alterations associated with insulin resistance and diabetes [53-58]. This is important and we must insist on the management of metabolic factors as well as appropriate therapeutic measures should be applied for their control, especially in obese patients who present a moderate or high risk of kidney disease [59]. 
Diabetes is another main factor associated with the development and progression of CKD. In the present study, the prevalence of EKD in the diabetic population was $15.4 \%$, with a trend to increasing compared to previous studies [60], and placing these values within the mean of the EU in this population group [34]. Curiously, one study analyzing data from 1988 to 2012 in an American diabetic population described stability in the prevalance of EKD, decreasing from $23.1 \%$ in the period 1988-1994 to $17.2 \%$ in the period from 2011-2012, which is very similar to what was observed in the present study. The authors attributed these results to greater control of metabolic parameters in the last years [61].

Lastly, AHT is closely related to CKD and is one of the main factors of risk for the development of this disease. In our study not only AHT but also blood pressure values considered as normal-high doubled the risk of EKD after adjustment for different confounding factors, only being surpassed by obesity which increased the risk 2.5-old and was the most important risk factor for developing EKD in men. Among the population with hypertension in the present study, EKD was present in $8.4 \%$, being within the range reported in the remaining countries of the EU [34].

Other metabolic alterations related to obesity such as low HDL or hypertriglyceridemia, which have shown an important relationship with the initial stages of kidney disease [5], were also found to be a risk factor in the present study, although this association was not statistically significant.

This study has several limitations: firstly, Although the selection of the sample was random, more women than men participated, due to a greater willingness to participate in the study. However, differences in gender distribution ( $43 \%$ men) are little compared with the real gender distribution among the population with the same age distribution in our area ( $47 \%$ men). Secondly, the calculation of the GFR was only performed based on one analytical determination which was not repeated at 3 months, implying stability of renal function. Some individuals may have been classified in an erroneous stage of kidney disease, but this would not have affected the results. On one hand, the analysis was performed in stages 1 and 2 together, and on the other hand, individuals erroneously classified in a stage lower than 1 or 2, and who were excluded from the study, represented a low percentage of the total sample. Thirdly, since the procedures were integrated in the usual clinical practice, the calculation of the GFR was initially performed using the MDRD-4 formula which was used by the reference laboratory and was later replaced by the CKD-EPI when this was implemented. This meant that stages 1 and 2 could not initially be differentiated, and some individuals were classified into different stages according to the formula used. Although MDRD-4 underestimates the GFR when this is above $60 \mathrm{~mL} / \mathrm{min} / 1.72 \mathrm{~m}^{2}$, a GFR lower than this value with both formulas is equivalent. Since the cut-off of the GFR used in the present study was $60 \mathrm{~mL} / \mathrm{min} / 1.73 \mathrm{~m}^{2}$, the results were not affected by the use of MDRD-4 or CKD-EPI. In addition, in most of the cases, the GFR calculated with MDRD-4 was recalculated with CKD-EPI. Fourthly, in determined situations such as the important loss of muscle mass, muscular diseases or morbid obesity, among others, the GFR cannot be calculated with the MDRD-4 or CKD-EPI, and therefore, 24-h urine clearance was the method of choice to evaluate kidney function in these cases. However, a very low percentage of these individuals were included in the study since most were excluded at the initiation of the study. Finally, although this study is population-based, note that it's derived from a study intended to estimate the prevalence of silent hepatic fibrosis. As a consequence, people with known chronic liver disease were excluded from the original study. This accounts for a $1.2 \%$ of the sample. This could slightly infraestimate the prevalence of EKD since liver and chronic diseases are associated.

\section{Conclusions}

The prevalence EKD among the general population is not negligible. It is clearly higher among men and increases with age. This prevalence significantly differs if the diagnosis is based on one or two analytical determinations, being overestimated if only one measurement is made and depends on the cut-off value chosen to define albuminuria. EKD was most frequent among obese subjects, diabetics and individuals with hypertension, and the factors independently associated with the prevalence of 
EKD were male gender, obesity, and blood pressure. Nonetheless, the origin of CKD is multifactorial, and the variability among the methodologies used in different studies should be reduced in order to focus on the factors which influence, and to what extent, the development of kidney disease in different populations and to provide adequate therapeutic interventions.

Author Contributions: Conceptualization, C.E., G.P., P.T., and L.C.; Methodology, C.E., G.P., and L.C.; Formal analysis, G.P., A.A., and M.D.; Investigation, C.E., L.R., I.A., and A.M.; Supervision, C.E., L.R., I.A., and A.M.; Validation, G.P., A.A., M.D., and L.C.; Writing-Original Draft Preparation, C.E., and P.T.; Writing-Review \& Editing, C.E., G.P, P.T., and L.C.; Funding Acquisition, L.C. All the authors read and approved the final manuscript.

Funding: The project received a research grant from the Carlos III Institute of Health, Ministry of Economy and Competitiveness (Spain), awarded on the 2011 call under the Health Strategy Action 2013-2016, within the National Research Program oriented to Societal Challenges, within the Technical, Scientific and Innovation Research National Plan 2013-2016, with reference PI11/0267, co-funded with European Union ERDF funds".

Conflicts of Interest: The authors declare no conflict of interest.

\section{References}

1. Schoolwerth, A.C.; Engelgau, M.M.; Hostetter, T.H.; Rufo, K.H.; Chianchiano, D.; McClellan, W.M.; Warnock, D.G.; Vinicor, F. Chronic kidney disease: A public health problem that needs a public health action plan. Prev. Chronic. Dis. 2006, 3, A57. [PubMed]

2. Levey, A.S.; Atkins, R.; Coresh, J.; Cohen, E.P.; Collins, A.J.; Eckardt, K.U.; Nahas, M.E.; Jaber, B.L.; Jadoul, M.; Levin, A.; et al. Chronic kidney disease as a global public health problem: Approaches and initiatives-A position statement from Kidney Disease Improving Global Outcomes. Kidney Int. 2007, 72, 247-259. [CrossRef] [PubMed]

3. Kidney Disease: Improving Global Outcomes (KDIGO) CKD Work Group. KDIGO 2012 Clinical Practice Guideline for the Evaluation and Management of Chronic Kidney Disease. Kidney Int. Suppl. 2013, 3, 1-150.

4. Martínez-Castelao, A.; Górriz, J.L.; Bover, J.; Segura-de la Morena, J.; Cebollada, J.; Escalada, J.; Esmatjes, E.; Fácila, L.; Gamarra, J.; Gràcia, S.; et al. Consensus document for the detection and management of chronic kidney disease. Atención Primaria 2014, 46, 501-519. [CrossRef] [PubMed]

5. Landecho, M.F.; Colina, I.; Huerta, A.; Fortuño, A.; Zalba, G.; Beloqui, O. Connection between the early phases of kidney disease and the metabolic syndrome. Rev. Esp. Cardiol. 2011, 64, 373-378. [CrossRef] [PubMed]

6. Coresh, J.; Astor, B.C.; Greene, T.; Eknoyan, G.; Levey, A.S. Prevalence of chronic kidney disease and decreased kidney function in the adult US population: Third National Health and Nutrition Examination Survey. Am. J. Kidney Dis. 2003, 41, 1-12. [CrossRef] [PubMed]

7. Coresh, J.; Selvin, E.; Stevens, L.A.; Manzi, J.; Kusek, J.W.; Eggers, P.; Van Lente, F.; Levey, A.S. Prevalence of chronic kidney disease in the United States. JAMA 2007, 298, 2038-2047. [CrossRef] [PubMed]

8. Chadban, S.J.; Briganti, E.M.; Kerr, P.G.; Dunstan, D.W.; Welborn, T.A.; Zimmet, P.Z.; Atkins, R.C. Prevalence of kidney damage in Australian adults: The Aus Diab kidney study. J. Am. Soc. Nephrol. 2003, 14, S131-S138. [CrossRef] [PubMed]

9. Magnason, R.L.; Indridason, O.S.; Sigvaldason, H.; Sigfusson, N.; Palsson, R. Prevalence and progression of CRF in Iceland: A population-based study. Am. J. Kidney Dis. 2002, 40, 955-963. [CrossRef] [PubMed]

10. Nwankwo, E.; Bello, A.K.; El Nahas, A.M. Chronic kidney disease: Stemming the global tide. Am. J. Kidney Dis. 2005, 45, 201-208. [CrossRef]

11. Jafar, T.H.; Schmid, C.H.; Levey, A.S. Serum creatinine as marker of kidney function in South Asians: A study of reduced GFR in adults in Pakistan. J. Am. Soc. Nephrol. 2005, 16, 1413-1419. [CrossRef] [PubMed]

12. Amato, D.; Alvarez-Aguilar, C.; Castañeda-Limones, R.; Rodriguez, E.; Avila-Diaz, M.; Arreola, F.; Gomez, A.; Ballesteros, H.; Becerril, R.; Paniagua, R. Prevalence of chronic kidney disease in an urban Mexican population. Kidney Int. Suppl. 2005, 97, S11-S17. [CrossRef] [PubMed]

13. Chen, J.; Wildman, R.P.; Gu, D.; Kusek, J.W.; Spruill, M.; Reynolds, K.; Liu, D.; Hamm, L.L.; Whelton, P.K.; $\mathrm{He}$, J. Prevalence of decreased kidney function in Chinese adults aged 35 to 74 years. Kidney Int. 2005, 68, 2837-2845. [CrossRef] [PubMed] 
14. Viktorsdottir, O.; Palsson, R.; Andresdottir, M.B.; Aspelund, T.; Gudnason, V.; Indridason, O.S. Prevalence of chronic kidney disease based on estimated glomerular filtration rate and proteinuria in Icelandic adults. Nephrol. Dial. Transplant. 2005, 20, 1799-1807. [CrossRef] [PubMed]

15. Hsu, C.C.; Hwang, S.J.; Wen, C.P.; Chang, H.Y.; Chen, T.; Shiu, R.S.; Horng, S.S.; Chang, Y.K.; Yamg, W.C. High prevalence and low awareness of CKD in Taiwan: A study on the relationship between serum creatinine and awareness from a nationally representative survey. Am. J. Kidney Dis. 2006, 48, 727-738. [CrossRef] [PubMed]

16. Hallan, S.I.; Coresh, J.; Astor, B.C.; Asberg, A.; Powe, N.R.; Romundstad, S.; Hallan, H.A.; Lydersen, S.; Holmen, J. International comparison of the relationship of chronic kidney disease prevalence and ESRD risk. J. Am. Soc. Nephrol. 2006, 17, 2275-2284. [CrossRef] [PubMed]

17. Djukanović, L.; Ležaić, V.; Dimković, N.; Peković, G.P.; Bukvić, D.; Bajčetić, S.; Pavlović, J.; Bontić, A.; Momćilović, D.; Stojanović, M. Early detection of chronic kidney disease: Collaboration of belgrade nephrologists and primary care physicians. Nefrologia 2012, 32, 59-66. [PubMed]

18. Bonet, J.; Vila, J.; Alsina, M.J.; Ancochea, L.; Romero, R.; Baetulo, G. Prevalencia de microalbuminuria en la población general de un área mediterránea española y su asociación con otros factores de riesgo cardiovascular. Med. Clin. 2001, 116, 573-574. [CrossRef]

19. Otero, A.; de Francisco, A.; Gayoso, P.; García, F. Prevalence of chronic renal disease in Spain: Results of the EPIRCE study. Nefrologia 2010, 30, 78-86.

20. Chen, F.; Yang, W.; Weng, J.; Jia, W.; Ji, L.; Xiao, J.; Shan, Z.; Liu, J.; Tian, H.; Ji, Q.; et al. Albuminuria: Prevalence, associated risk factors and relationship with cardiovascular disease. J. Diabetes Investig. 2014, 5, 464-471. [CrossRef]

21. Montañes, R.; Gràcia, S.; Pérez, D.; Martínez, A.; Bover, J. Documento de Consenso. Recomendaciones sobre la valoración de la proteinuria en el diagnóstico y seguimiento de la enfermedad renal crónica. Nefrologia 2011, 31, 331-345.

22. American Diabetes Association. Standards of Medical Care in Diabetes-2010. Diabetes Care 2010, 33, S11-S61. [CrossRef] [PubMed]

23. Chobanian, A.V.; Bakris, G.L.; Black, H.R.; Cushman, W.C.; Green, L.A.; Izzo, J.L., Jr.; Jones, D.W.; Materson, B.J.; Oparil, S.; Wright, J.T., Jr.; et al. Seventh report of the Joint National Committee on Prevention, Detection, Evaluation, and Treatment of High Blood Pressure. Hypertension 2003, 42, 1206-1252. [CrossRef] [PubMed]

24. The CARI guidelines. Urine protein as diagnostic test: Testing for proteinuria. Nephrology 2004, 9, S3-S7.

25. Burden, R.; Tomson, C.; Joint Specialty Committee on Renal Disease; Renal Association. Identification, management and referral of adults with chronic kidney disease: Concise guidelines. Clin. Med. 2005, 5, 635-642. [CrossRef] [PubMed]

26. Scottish Intercollegiate Guidelines Network. Diagnosis and Management of Chronic Kidney Disease-A National Clinical Guideline; Scottish Intercoll Guidel Network: Edinburgh, UK, 2008; pp. 1-57.

27. Levey, A.S.; Lesley, A.I. Definition and Staging of Chronic Kidney Disease in Adults. Available online: http://www.uptodate.com/contents/definition-and-staging-of-chronic-kidnedisease-in-adults (accessed on 5 April 2017).

28. Bernelot Moens, S.J.; Verweij, S.L.; van der Valk, F.M.; van Capelleveen, J.C.; Kroon, J.; Versloot, M.; Verbeme, H.J.; Marquering, H.A.; Duivenvoorden, R.; Vogt, L.; et al. Arterial and Cellular Inflammation in Patients with CKD. J. Am. Soc. Nephrol. 2017, 28, 1278-1285. [CrossRef] [PubMed]

29. Caballería, L.; Pera, G.; Arteaga, I.; Rodríguez, L.; Alumà, A.; Morillas, R.M.; de la Ossa, N.; Díaz, A.; Expósito, C.; Miranda, D.; et al. High Prevalence of Liver Fibrosis Among European Adults With Unknown Liver Disease: A Population-Based Study. Clin. Gastroenterol. Hepatol. 2018, 16, 1138-1145. [CrossRef]

30. Levey, A.S.; Bosch, J.P.; Lewis, J.B.; Greene, T.; Rogers, N.; Roth, D. A more accurate method to estimate glomerular filtration rate from serum creatinine: A new prediction equation. Modification of Diet in Renal Disease Study Group. Ann. Intern. Med. 1999, 130, 461-470. [CrossRef]

31. Levey, A.S.; Greene, T.; Kusek, J.W.; Beck, G.J.; MDRD Study Group. A simplified equation to predict glomerular filtration rate from serum creatinine. J. Am. Soc. Nephrol. 2000, 11, A155.

32. Levey, A.S.; Stevens, L.A.; Schmid, C.H.; Zhang, Y.L.; Castro, A.F.; Feldman, H.I.; Kusek, J.W.; Eggers, P.; Van Lente, F.; Greene, T.; et al. A new equation to estimate glomerular filtration rate. Ann. Intern. Med. 2009, 150, 604-612. [CrossRef] 
33. Levey, A.S.; Stevens, L.A.; Coresh, J. Conceptual Model of CKD: Applications and Implications. Am. J. Kidney Dis. 2009, 53, S4-S16. [CrossRef] [PubMed]

34. Brück, K.; Stel, V.S.; Gambaro, G.; Hallan, S.; Völzke, H.; Ärnlöv, J.; Kastarinen, M.; Guessous, I.; Vinhas, J.; Stengel, B.; et al. CKD Prevalence Varies across the European General Population. J. Am. Soc. Nephrol. 2016, 27, 2135-2147. [CrossRef] [PubMed]

35. Hill, N.R.; Fatoba, S.T.; Oke, J.L.; Hirst, J.A.; O'Callaghan, C.A.; Lasserson, D.S.; Hobbs, F.D. Global Prevalence of Chronic Kidney Disease-A Systematic Review and Meta-Analysis. PLoS ONE 2016, 11, e0158765. [CrossRef] [PubMed]

36. Gorostidi, M.; Sánchez-Martínez, M.; Ruilope, L.M.; Graciani, A.; de la Cruz, J.J.; Santamaría, R.; Del Pino, M.D.; Guallar-Castillón, P.; de Álvaro, F.; Rodríguez-Artalejo, F.; et al. Chronic kidney disease in Spain: Prevalence and impact of accumulation of cardiovascular risk factors. Nefrologia 2018, 38, 606-615. [CrossRef] [PubMed]

37. Gheewala, P.A.; Zaidi, S.T.R.; Jose, M.D.; Bereznicki, L.; Peterson, G.M.; Castelino, R.L. Effectiveness of targeted screening for chronic kidney disease in the community setting: A systematic review. J. Nephrol. 2018, 31, 27-36. [CrossRef] [PubMed]

38. Inker, L.A.; Perrone, R.D. Assessment of Kidney Function; Stems, R.H., Ed.; UpToDate: Waltham, MA, USA, 2018. Available online: https://www.uptodate.com/contents/assessment-of-kidney-function (accessed on 18 February 2019).

39. Heathcote, K.L.; Wilson, M.P.; Quest, D.W.; Wilson, T.W. Prevalence and duration of exercise induced albuminuria in healthy people. Clin. Invest. Med. 2009, 32, E261-E265. [CrossRef] [PubMed]

40. Levey, A.S.; de Jong, P.E.; Coresh, J.; El Nahas, M.; Astor, B.C.; Matsushita, K.; Gansevoort, R.T.; Kasiske, B.L.; Eckardt, K.U. The definition, classification, and prognosis of chronic kidney disease: A KDIGO Controversies Conference report. Kidney Int. 2011, 80, 17-28. [CrossRef] [PubMed]

41. Chronic Kidney Disease Prognosis Consortium; Matsushita, K.; van der Velde, M.; Astor, B.C.; Woodward, M.; Levey, A.S.; de Jong, P.E.; Coresh, J.; Gansevoort, R.T. Association of estimated glomerular filtration rate and albuminuria with all-cause and cardiovascular mortality in general population cohorts: A collaborative meta-analysis. Lancet 2010, 375, 2073-2081. [PubMed]

42. Hallan, S.I.; Matsushita, K.; Sang, Y.; Mahmoodi, B.K.; Black, C.; Ishani, A.; Kleefstra, N.; Naimark, D.; Roderick, P.; Tonelli, M.; et al. Age and the Association of Kidney Measures with Mortality and End-Stage Renal Disease. JAMA 2012, 308, 2349-2360. [CrossRef]

43. Ji, E.; Kim, Y.S. Prevalence of chronic kidney disease defined by using CKD-EPI equation and albumin-to-creatinine ratio in the Korean adult population. Korean J. Intern. Med. 2016, 31, 1120-1130. [CrossRef]

44. Drion, I.; Cobbaert, C.; Groenier, K.H.; Weykamp, C.; Bilo, H.J.; Wetzels, J.F.; Kleefstra, N. Clinical evaluation of analytical variations in serum creatinine measurements: Why laboratories should abandon Jaffe techniques. BMC Nephrol. 2012, 13, 133. [CrossRef] [PubMed]

45. Bachmann, L.M.; Nilsson, G.; Bruns, D.E.; McQueen, M.J.; Lieske, J.C.; Zakowski, J.J.; Miller, W.G. State of the art for measurement of urine albumin: Comparison of routine measurement procedures to isotope dilution tandem mass spectrometry. Clin. Chem. 2014, 60, 471-480. [CrossRef] [PubMed]

46. Coresh, J.; Byrd-Holt, D.; Astor, B.C.; Briggs, J.P.; Eggers, P.W.; Lacher, D.A.; Hostetter, T.H. Chronic kidney disease awareness, prevalence, and trends among U.S. adults, 1999 to 2000. J. Am. Soc. Nephrol. 2005, 16, 180-188. [CrossRef] [PubMed]

47. Warram, J.H.; Gearin, G.; Laffel, L.; Krolewski, A.S. Effect of duration of type I diabetes on the prevalence of stages of diabetic nephropathy defined by urinary albumin/creatinine ratio. J. Am. Soc. Nephrol. 1996, 7, 930-937.

48. Taal, M.; Tomson, C. Clinical practice guidelines for the care of patients with chronic kidney disease. In UK Renal Association Clinical Practice Guidelines, 4th ed.; The Renal Association: Bristol, UK, 2007. Available online: www.renal.org/guidelines (accessed on 12 November 2018).

49. Johnson, D.W.; Atai, E.; Chan, M.; Phoon, R.K.; Scott, C.; Toussaint, N.D.; Turner, G.L.; Usherwood, T.; Wiggins, K.J.; KHA-CARI. KHA-CARI guideline: Early chronic kidney disease: Detection, prevention and management. Nephrology 2013, 18, 340-350. [CrossRef] [PubMed]

50. Fox, C.S.; Larson, M.G.; Leip, E.P.; Culleton, B.; Wilson, P.W.F.; Levy, D. Predictors of new-onset kidney disease in a community-based population. JAMA 2004, 291, 844-850. [CrossRef] [PubMed] 
51. Flegal, K.M.; Kruszon-Moran, D.; Carroll, M.D.; Fryar, C.D.; Ogden, C.L. Trends in Obesity Among Adults in the United States, 2005 to 2014. JAMA 2016, 315, 2284-2291. [CrossRef]

52. Aranceta-Bartrina, J.; Perez-Rodrigo, C.; Alberdi-Aresti, G.; Ramos-Carrera, N.; Lazaro-Masedo, S. Prevalencia de obesidad general y obesidad abdominal en la poblacion adulta española (25-64 años) 2014-2015: Estudio ENPE. Rev. Esp. Cardiol. 2016, 69, 579-587. [CrossRef]

53. Maric, C.; Hall, J.E. Obesity, Metabolic Syndrome and Diabetic Nephropathy. NIH Public Access. 2011, 170, 28-35.

54. Musso, G.; Gambino, R.; Tabibian, J.H.; Ekstedt, M.; Kechagias, S.; Hamaguchi, M.; Hultcrantz, R.; Hagström, H.; Yoon, S.K.; Charatcharoenwitthaya, P.; et al. Association of non-alcoholic fatty liver disease with chronic kidney disease: A systematic review and meta-analysis. PLoS Med. 2014, 11, e1001680. [CrossRef]

55. Targher, G.; Chonchol, M.B.; Byrne, C.D. CKD and Nonalcoholic Fatty Liver Disease. Am. J. Kidney Dis. 2014, 64, 638-652. [CrossRef] [PubMed]

56. Escasany, E.; Izquierdo-Lahuerta, A.; Medina-Gomez, G. Underlying Mechanisms of Renal Lipotoxicity in Obesity. Nephron 2019, 143, 28-32. [CrossRef] [PubMed]

57. Mende, C.; Einhorn, D. Fatty kidney disease: A new renal and endocrine clinical entity? Describing the role of the kidney in obesity, metabolic syndrome, and type 2 diabetes. Endocr. Pract. 2019, 25, 854-858. [CrossRef] [PubMed]

58. Silva Junior, G.; Bentes, A.; Daher, E.; Matos, S. Obesity and kidney disease. J. Bras. Nefrol. 2017, 39, 65-69. [CrossRef] [PubMed]

59. Lin, Y.C.; Lai, Y.J.; Lin, Y.C.; Peng, C.C.; Chen, K.C.; Chuang, M.T.; Wu, M.S.; Chang, T.H. Effect of weight loss on the estimated glomerular filtration rates of obese patients at risk of chronic kidney disease: The RIGOR-TMU study. J. Cachexia Sarcopenia Muscle 2019, 10, 756-766. [CrossRef] [PubMed]

60. Rodriguez-Poncelas, A.; Garre-Olmo, J.; Franch-Nadal, J.; Diez-Espino, J.; Mundet-Tuduri, X.; Barrot-De la Puente, J.; Coll-de Tuero, G.; RedGDPS Study Group. Prevalence of chronic kidney disease in patients with type 2 diabetes in Spain: PERCEDIME2 study. BMC Nephrol. 2013, 14, 46. [CrossRef] [PubMed]

61. Murphy, D.; McCulloch, C.E.; Lin, F.; Banerjee, T.; Bragg-Gresham, J.L.; Eberhardt, M.S.; Morgenstern, H.; Pavkov, M.E.; Saran, R.; Powe, N.R.; et al. Trends in Prevalence of Chronic Kidney Disease in the United States. Ann. Intern. Med. 2016, 165, 473-481. [CrossRef] [PubMed] 